\title{
Marco Polo, Le devisement du monde, tome III, L' empereur Khoubilai Khan, tome IV, Voyage à travers la Chine
}

\section{G. Matteo Roccati}

\section{(2) OpenEdition}

\section{Journals}

Édition électronique

URL : http://journals.openedition.org/studifrancesi/27223

DOI : 10.4000/studifrancesi.27223

ISSN : 2421-5856

Éditeur

Rosenberg \& Sellier

Édition imprimée

Date de publication : 31 décembre 2006

Pagination : 576

ISSN : 0039-2944

Référence électronique

G. Matteo Roccati, «Marco Polo, Le devisement du monde, tome III, L'empereur Khoubilai Khan, tome IV, Voyage à travers la Chine », Studi Francesi [En ligne], 150 (L | III) | 2006, mis en ligne le 30 novembre 2015, consulté le 08 novembre 2020. URL : http://journals.openedition.org/studifrancesi/27223 ; DOI : https://doi.org/10.4000/studifrancesi.27223

Ce document a été généré automatiquement le 8 novembre 2020.

\section{c) (†)}

Studi Francesi è distribuita con Licenza Creative Commons Attribuzione - Non commerciale - Non opere derivate 4.0 Internazionale. 


\title{
Marco Polo, Le devisement du monde, tome III, L'empereur Khoubilai Khan, tome IV, Voyage à travers la Chine
}

\author{
G. Matteo Roccati
}

\section{RÉFÉRENCE}

MARCo POLO, Le devisement du monde, Édition critique publiée sous la direction de Philippe MÉNARD, tome III, L'empereur Khoubilai Khan, édité par Jean-Claude FAUCoN, Danielle QUÉRUEL, Monique SANTUCCI, Genève, Librairie Droz S.A. («Textes littéraires français», 568), 2004; pp. 216.

1 L'édition collective de la version française, prévue en six volumes, se poursuit. Le tome III (ch. 75-104) est entièrement consacré au Grand Khan et les éditeurs soulignent dans l'introduction les accents d'authenticité dont est empreint le texte, accents révélant le témoin oculaire désireux de transmettre son émerveillement. Le tome IV (ch. 104-137) raconte en revanche de manière «objective», didactique (la plupart du temps en utilisant le «on» indéfini), les voyages accomplis par Marco, chargé de mission du Grand Khan, dans les différentes régions de la Chine, en particulier dans le sud-ouest.

Comme dans les deux premiers tomes (voir Rassegna, t. XLVII, $n^{\circ}$ 140, pp. 415-416; $t$. XLVIII, $n^{\circ} 144$, p. 581), l'introduction s'appuie sur la partie du texte éditée pour traiter de la tradition manuscrite et de la langue du manuscrit de base (Londres, BL, Royal $19 \mathrm{D}$ 1 (B1)). Elle analyse aussi brièvement le contenu et les traits marquants de la portion de texte objet du volume, et fournit une bibliographie sélective. L'édition indique les leçons rejetées en bas de page; elle est suivie des notes, des variantes, de l'index des noms propres, du glossaire et de quelques illustrations (reproductions et cartes). 